\title{
Thermal Analysis of Cover Systems in Municipal Solid Waste Landfills
}

\author{
Nazlı Yeşiller, Ph.D., A.M.ASCE${ }^{1}$; James L. Hanson, Ph.D., P.E., M.ASCE²; Nicolas K. Oettle, A.M.ASCE³ \\ and Wei-Lien Liu, Ph.D., A.M.ASCE ${ }^{4}$
}

\begin{abstract}
Cover temperature variations were determined at four municipal solid waste landfills located in different climatic regions in North America: Michigan, New Mexico, Alaska, and British Columbia. Cover temperatures varied seasonally similarly to air temperatures and demonstrated amplitude decrement and phase lag with depth. Elevated temperatures in the underlying wastes resulted in warmer temperatures and low frost penetration in the covers compared to surrounding subgrade soils. The ranges of measured temperatures decreased and average temperatures generally increased (approximately $2^{\circ} \mathrm{C} / \mathrm{m}$ ) with depth. The ranges of measured temperatures $\left(T_{\max }-T_{\min }\right)$ were $18-30^{\circ} \mathrm{C}$ and $13-21^{\circ} \mathrm{C}$ and the average temperatures were $13-18^{\circ} \mathrm{C}$ and $14-23^{\circ} \mathrm{C}$ at 1 and $2 \mathrm{~m}$ depths, respectively. For soil and geosynthetic barrier materials around $1 \mathrm{~m}$ depth, the maximum and minimum temperatures were $22-25^{\circ} \mathrm{C}$ and $3-4^{\circ} \mathrm{C}$, respectively. Frost depths were determined to be approximately 50\% of those for soils at ambient conditions. The main direction of heat flow in the covers was upward (negative gradients). The cover gradients varied between -18 and $14{ }^{\circ} \mathrm{C} / \mathrm{m}$, with averages of -7 to $1{ }^{\circ} \mathrm{C} / \mathrm{m}$. The gradients for soil and geosynthetic barrier materials around $1 \mathrm{~m}$ depth varied between -11 and $9{ }^{\circ} \mathrm{C} / \mathrm{m}$ with an average of $-2{ }^{\circ} \mathrm{C} / \mathrm{m}$. Cover thawing $n$-factors ranged between 1.0 and 1.4 and the cover freezing $n$-factor was 0.6 . Design charts and guidelines are provided for cover thermal analyses for variable climatic conditions.
\end{abstract}

CE Database subject headings: Temperature effects; Landfills; Municipal wastes; Solid waste; Geomembranes; Material properties.

\section{Introduction}

Temperature affects individual material properties and composite system response of covers used in landfills. Fundamental engineering properties of both earthen and geosynthetic materials used in covers as well as the integrity, durability, and service life of cover systems are affected by temperature. In general, elevated temperatures have direct, adverse effects on cover materials including desiccation cracking of earthen barriers; decrease in shear strength of soils; accelerated ageing and decreased service life of geosynthetics; and expansion of geomembranes causing wrinkles (Soong and Koerner 1999; Koerner 2005; Mitchell and Soga 2005; Rowe 2005). Cyclic temperatures and associated wet/dry and freeze/thaw cycles also have adverse effects on earthen barriers including low permeability soil liners and geosynthetic clay liners (GCLs). Cracking of the barriers that occurs due to these effects results in increases in flow of fluids as demonstrated in

\footnotetext{
${ }^{1}$ Lecturer, Civil and Environmental Engineering Dept., California Polytechnic State Univ., San Luis Obispo, CA 93407 (corresponding author). E-mail: nyesiller@gmail.com

${ }^{2}$ Associate Professor, Civil and Environmental Engineering Dept., California Polytechnic State Univ., San Luis Obispo, CA 93407.

${ }^{3}$ Staff Engineer, Geosyntec Consultants, Huntington Beach, CA 92648.

${ }^{4}$ Senior Staff Engineer, CTI and Associates, Inc., Brighton, MI 48116.
}

several studies (Benson and Othman 1993; Benson et al. 1995; Albrecht and Benson 2001; Bouazza et al. 2006). In addition, thermal gradients cause coupled moisture transfer and lead to desiccation cracking of soil liners and GCLs (Doll 1997; Southen and Rowe 2005). In the field, thermal effects were reported to contribute to GCL seam separations (Koerner and Koerner 2005) and soil temperature was indicated to be the dominating factor for methane emissions from an earthen cover (Borjesson and Svensson 1997). Summaries of temperature effects on barrier systems are provided in Rowe (2005) and NRC (2007).

Even though temperature significantly affects cover systems, published field data are highly limited. Minimum and maximum temperatures $0.75 \mathrm{~m}$ below the ground surface were reported to be approximately 0 and $30^{\circ} \mathrm{C}$, respectively, at a municipal solid waste (MSW) landfill (Koerner and Koerner 2006). The landfill was located in an area with an annual precipitation of $1,045 \mathrm{~mm}$ and a mean annual air temperature of $12.6^{\circ} \mathrm{C}$. The cover temperatures were reported to be dominated by ambient air temperature cycles and not by underlying elevated waste temperatures. However, a description of responsible mechanisms was not provided.

This study was conducted to provide realistic thermal service conditions for cover systems. A field investigation was conducted at MSW landfills in four distinct climatic regions to determine temperature distributions and thermal gradients in covers under combined effects of overlying air temperature fluctuations and underlying waste heat generation. Numerical analysis was used to estimate cover temperatures. Guidelines are provided for thermal response of cover systems as a function of local climatic and underlying waste conditions. 
Table 1. Climate Statistics at the Study Sites

\begin{tabular}{|c|c|c|c|c|}
\hline Parameter & Michigan $^{\mathrm{b}}$ & New Mexico ${ }^{\mathrm{b}}$ & Alaska $^{\mathrm{b}}$ & British Columbia $^{c}$ \\
\hline Climatic zone $^{\mathrm{a}}$ & Cool temperate & Warm-temperate subtropical & Cold temperate boreal & Cool temperate \\
\hline Climate description $^{\mathrm{a}}$ & Humid continental temperate & Semidesert & Oceanic boreal & Woodland oceanic \\
\hline Average $T_{\text {high }}\left({ }^{\circ} \mathrm{C}\right)$ & 14.7 & 25.1 & 6.2 & 13.5 \\
\hline Average $T_{\text {low }}\left({ }^{\circ} \mathrm{C}\right)$ & 5 & 11.2 & -1.5 & 6.1 \\
\hline Average $T\left({ }^{\circ} \mathrm{C}\right)$ & 9.8 & 18.2 & 2.3 & 9.9 \\
\hline Annual normal precipitation (mm) & 835 & 240 & 408 & 1,167 \\
\hline Annual normal snowfall (mm) & 1,046 & 135 & 1,793 & 549 \\
\hline
\end{tabular}

${ }^{\mathrm{a}}$ Based on Landsberg et al. (1966).

${ }^{\mathrm{b}}$ From NCDC (2006).

${ }^{\mathrm{c}}$ From MSC (2007).

\section{Testing Program}

The testing program consisted of a field investigation of temperatures in permanent and temporary cover systems at MSW landfills with varying climatic and operational conditions.

\section{Field Sites}

The study was conducted at four municipal solid waste landfills located in different climatic regions in North America: Michigan, New Mexico, Alaska, and British Columbia. The climate statistics for the sites are summarized in Table 1. The facilities located in Michigan, New Mexico, and Alaska are modern landfills with Subtitle D liner systems (barriers and leachate collection systems). The facility in British Columbia contains a base support/ liner system and a gravity-flow leachate collection system.

\section{Cover Systems}

Field data were collected in permanent and temporary cover systems at the sites. In Michigan, data were obtained in both cover types. The permanent cover was a geomembranecompacted clay single composite barrier system. From top to bottom, the cover consisted of top soil, soil protective layer, geonet-geotextile composite, geomembrane [high density polyethylene (HDPE) $1.5 \mathrm{~mm}$ thickness], compacted lean clay (CL), and a foundation layer placed immediately above wastes. Temperatures were obtained in temporary covers at the other sites, as permanent covers have not yet been installed. These consisted of approximately 600-1,000-mm-thick native soils at all sites. Temporary and permanent covers were investigated together as the thermal properties of soil components of the two cover types were similar and the presence of thin geosynthetic layers in the permanent covers did not have significant effects on thermal response.

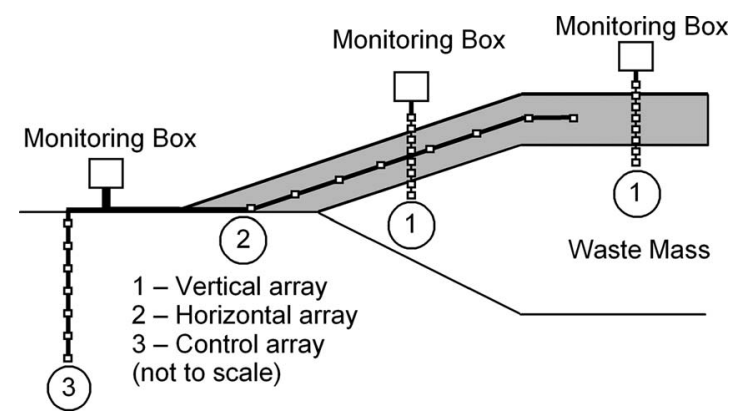

Fig. 1. Temperature measurement arrays

\section{Temperature Measurements}

Temperature data have been obtained using custom-designed sensor arrays that included multiple sensors placed along a linear path. The arrays consisted of thermocouple wire placed inside flexible polyvinyl chloride (PVC) conduit. Type K thermocouple wires (Nickel alloys, $\mathrm{Ni}-\mathrm{Cr} / \mathrm{Ni}-\mathrm{Mn}-\mathrm{Al}$ ) were used due to their resistance to chemical environments. Temperature data were collected weekly using a digital thermometer. The precision of the temperature measurements was $\pm 0.1^{\circ} \mathrm{C}$.

The two types of arrays used in the investigation were: vertical-placed perpendicular to the plane of the covers, and horizontal-placed parallel to the plane of the covers (Fig. 1). Vertical arrays were installed by drilling boreholes using a drill rig or hand auger. Powder bentonite was used to fill the annular space around the sensor arrays to prevent convection and restore the integrity of the cover systems. Control arrays were installed in the nearby soils (10-100 m away from landfill cells) to provide baseline temperatures at equivalent depths, which were not influenced by the presence of wastes (Fig. 1). Horizontal arrays were installed near the bottom of or immediately beneath the soils in temporary covers. Temperatures were measured in three cells in Michigan, one cell in Alaska, one cell in New Mexico, and five cells in British Columbia. Details of waste state in the vicinity of the sensor arrays are provided in Table 2 .

Table 2. Waste Conditions in Vicinity of Arrays

\begin{tabular}{lccc}
\hline & $\begin{array}{c}\text { Depth } \\
\text { of waste } \\
\text { below } \\
\text { surface } \\
(\mathrm{m})\end{array}$ & $\begin{array}{c}\text { Range } \\
\text { of waste } \\
\text { age } \\
\text { (years) }\end{array}$ & $\begin{array}{c}\text { Max. stable } \\
\text { waste } \\
\text { temperature } \\
\text { below array } \\
\left({ }^{\circ} \mathrm{C}\right)\end{array}$ \\
\hline Mensor array & 14.6 & $6-7.2$ & 60 \\
Michigan J & 12.3 & $12-12.7$ & Not available \\
Michigan D (horizontal) & $0-22.8$ & $2.8-3.8$ & 57 \\
New Mexico Cell 1 center & 18.6 & $5.8-10$ & 31 \\
New Mexico Cell 1 edge & 19.2 & $4.8-10$ & 32 \\
Alaska Cell 1A & 51.4 & $3-17$ & 25 \\
Alaska Cell 1B & 43.4 & $3-17$ & 19 \\
Alaska Cell 1C & 49.7 & $3-17$ & 20 \\
Alaska Cell 1 (horizontal) & $0-41$ & $3-17$ & Not available \\
British Columbia A & 17 & $24-40$ & 27 \\
British Columbia B and B detail & 19 & $16-24$ & 27 \\
British Columbia C & 17 & $13-16$ & 24 \\
British Columbia D & 17 & $10-12$ & 30 \\
British Columbia E & 19 & $8-10$ & 37 \\
\hline
\end{tabular}




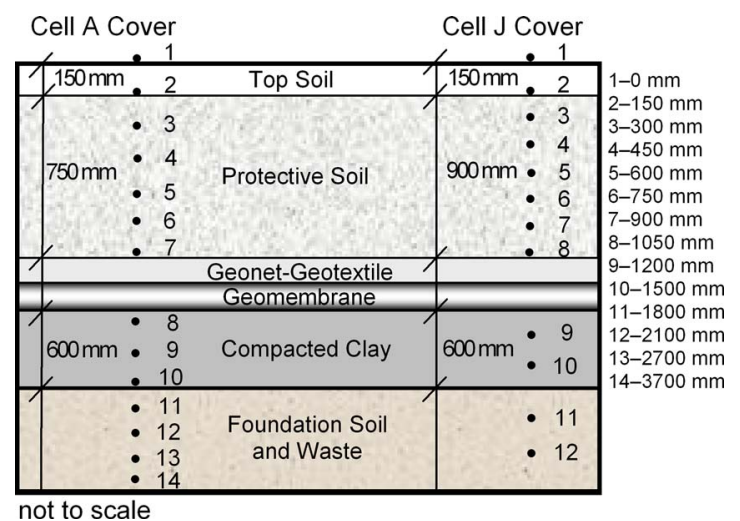

Fig. 2. Cover profiles in Michigan

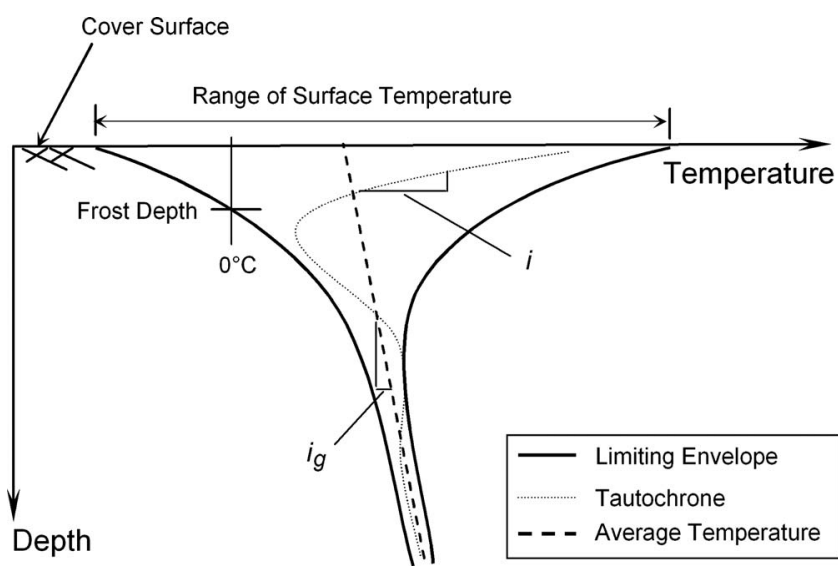

Fig. 3. Schematic representation of thermal parameters for covers
In Michigan, two vertical arrays (Cells A and J) and one horizontal array (Cell D) were installed. Detailed arrays with closely spaced sensors were installed in the permanent covers (Fig. 2). Cell $\mathrm{A}$ and $\mathrm{J}$ installations were made on north- and east-facing slopes, respectively. In Alaska, three vertical arrays (Cells 1A, 1B, and 1C) and one horizontal array (Cell 1) were installed. The sensors were located near the ground surface ( $0.3 \mathrm{~m}$ depth), $1.3 \mathrm{~m}$ depth, and $2.3 \mathrm{~m}$ depth in the vertical arrays. The horizontal arrays at both sites extended $40 \mathrm{~m}$ from the perimeter edge of the cells along upward slopes with sensors placed at $10 \mathrm{~m}$ nominal spacings.

In New Mexico, two vertical arrays (Cell 1 center and edge) were installed. The sensors were located at the surface $(0 \mathrm{~m}$ depth) and $2 \mathrm{~m}$ depth. In British Columbia, a total of six vertical arrays was installed. The sensors were located at the surface $(0 \mathrm{~m}$ depth), $1 \mathrm{~m}$ depth, and $2 \mathrm{~m}$ depth in Cells A, B, D, and E. The sensors were placed at $0.5,1.5$, and $2.5 \mathrm{~m}$ depths in Cell C. A second array placed in Cell B (Cell B detail) included seven sensors at $0,150,300,450,600,750$, and $900 \mathrm{~mm}$ depths and constituted the third detailed array of the study.

\section{Analyses}

\section{Field Investigation}

Initially, spatial and temporal variations of the field-measured temperatures were analyzed using both vertical and horizontal arrays. The maximum number of years with complete temperature data between July 1 and June 30 were used (total 2-3 years). Measured data were used directly in the analysis. Also, sinusoidal least-square regression functions were used to obtain idealized temperature versus time relationships that provide generalized trends without the effects of measurement schedule and frequency (e.g., extreme limiting temperatures, nonuniform durations between measurements, time of day of surveys). In addition, tautochrones (instantaneous temperature-depth profiles) were analyzed (Fig. 3).

Then, thermal gradients were determined using data from both vertical and horizontal arrays. Localized instantaneous temperature gradients $(i)$ were determined as the quotient of the temperature difference between two sensors within an array and the distance between the sensors using measured temperatures from a single monitoring event (Fig. 3). Positive gradients correspond to downward heat flow for vertical arrays and heat flow from the perimeter edges toward the central locations of a cell for horizon- tal arrays. Absolute values were also used to represent thermal gradients, irrespective of flow direction. Global thermal gradient $\left(i_{g}\right)$ was defined as the slope of the average temperature versus depth relationship (Fig. 3). Temporal variations and trends were analyzed for both temperatures and instantaneous gradients to determine rates of change and time periods associated with the limiting (maximum and minimum) temperatures and gradients.

\section{Analytical Investigation}

Analysis was conducted to develop seasonal surface temperature functions for the covers. Bias was produced in the measured surface data due to the time of day that weekly surface measurements were taken and the high diurnal variations at the surface. Representative sinusoidal cover surface temperature functions were developed using measured air and below-surface temperatures. Parameters required to define the functions were surface temperature amplitude and nonzero center amplitude (i.e., average surface temperature). The surface amplitude was determined by extrapolating amplitudes from near-surface depths upward using an exponential function. The average surface temperature was determined by interpolating between average air temperature and near-surface average cover temperatures. While the air temperatures were used directly, weighting factors were applied to the below surface temperatures to account for the variation in average temperatures with depth in covers due to underlying waste heat generation. The weighting factors were developed using data from the detailed arrays and averaged values for a given depth were applied to all sites (Oettle 2008).

Analysis was also conducted to determine surface $n$-factors for landfill covers. Use of $n$-factors allows for estimating cover surface temperatures from measured air temperatures, providing a convenient means to indirectly determine landfill cover temperature profiles (without the need for field measurements). The freezing and thawing surface $n$-factors were determined as the quotient of paired surface and air indices for freeze or thaw. The indices were determined as the area bound by a temperature-time curve and the $0^{\circ} \mathrm{C}$ baseline with area below $0^{\circ} \mathrm{C}$ for freezing and area above $0^{\circ} \mathrm{C}$ for thawing (Aldrich and Paynter 1953; Andersland and Ladanyi 1994). Average daily air temperatures were used to determine air freezing and thawing indices. The surface temperature functions were used to determine surface freezing and thawing indices.

Design charts were developed to estimate depths of limiting temperature range and frost penetration in cover systems using 


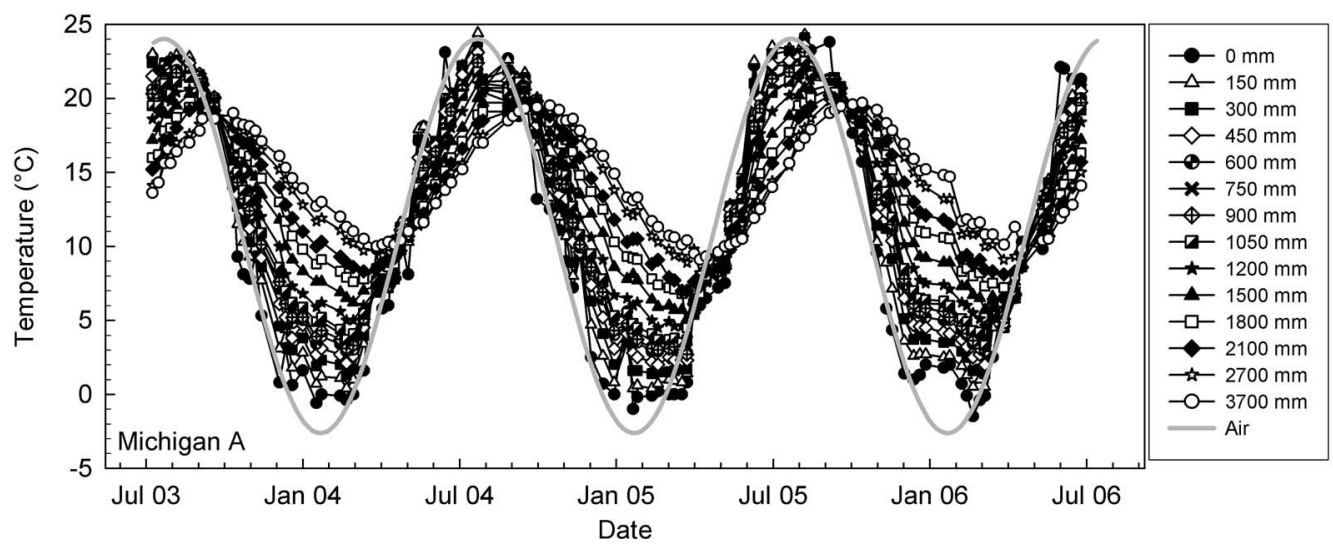

a) Temperature vs. time

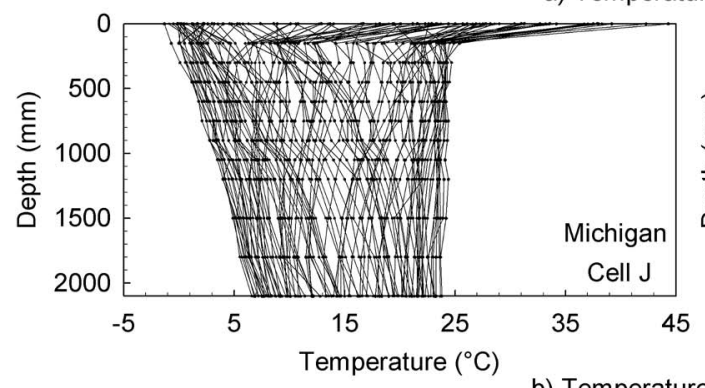

b) Temperature vs. depth

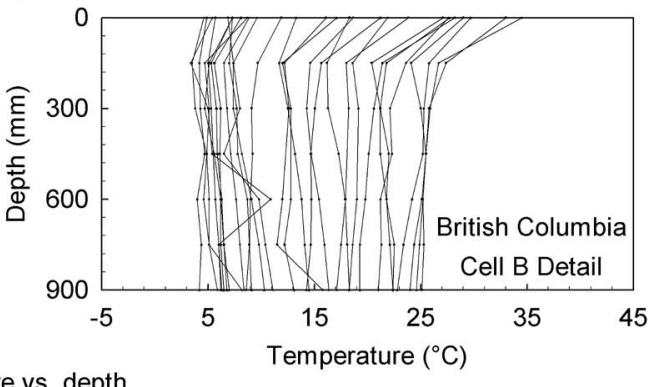

Fig. 4. Examples of variation of cover temperatures

seasonal earth temperature theory (Carslaw and Jaeger 1959; ORNL 1981). Phase lag analysis (ORNL 1981) was used to determine in-service cover (i.e., cover over waste) thermal diffusivity $\left(\alpha_{c}\right)$ at each site. The $\alpha_{c}$ values were $7.4 \times 10^{-7}, 6.0 \times 10^{-7}$, $3.3 \times 10^{-7}$, and $1.4 \times 10^{-6} \mathrm{~m}^{2} / \mathrm{s}$ in Michigan, New Mexico, Alaska, and British Columbia, respectively with a nominal average of $8 \times 10^{-7} \mathrm{~m}^{2} / \mathrm{s}$. Modified temperature envelopes with depth were generated for cover systems by linearly increasing average temperature with depth to account for elevated temperatures of underlying waste (Fig. 3). The average temperature increase for the study sites was $2^{\circ} \mathrm{C} / \mathrm{m}$ (further described below in " $\mathrm{Re}$ sults"). The envelopes were generated using the average $\alpha_{c}$ for all sites with a wide range of surface amplitudes $\left(0-25^{\circ} \mathrm{C}\right)$ and average surface temperatures $\left(0-25^{\circ} \mathrm{C}\right)$. The limiting temperature ranges at depth were determined as the difference between maximum and minimum temperatures of the envelope. The frost depths were determined as the intercept of the temperature-depth envelope with $0^{\circ} \mathrm{C}$. Details of the analysis are presented in Oettle (2008).

\section{Numerical Investigation}

Numerical analysis was conducted to determine the expected range of thermal response of covers as a function of climate, underlying stable waste temperatures at depth, and seasonal schedule of waste placement using a transient model. Modeling of coupled moisture flow and deformation of covers to provide close approximation of field behavior was beyond the scope of this study. The numerical investigation was conducted using finite-element analysis (ABAQUS version 6.7-1). Onedimensional linear heat transfer elements with a length of $0.1 \mathrm{~m}$ were used. Site-specific constant thermal properties used in the analyses were determined based on site records, laboratory tests, and field tests (Liu 2007). Thermal diffusivities used for wastes $\left(\alpha_{w}\right)$ were $5.0 \times 10^{-7}, 5.0 \times 10^{-7}, 3.0 \times 10^{-7}$, and $7.0 \times 10^{-7} \mathrm{~m}^{2} / \mathrm{s}$ and thermal diffusivities of cover soils $\left(\alpha_{s}\right)$ were $9.0 \times 10^{-7}, 4.9 \times 10^{-7}, 1.3 \times 10^{-6}$, and $3.3 \times 10^{-7} \mathrm{~m}^{2} / \mathrm{s}$ in Michigan, New Mexico, Alaska, and British Columbia, respectively. The latent heats for wastes $\left(L_{w}\right)$ were 95 and $56 \mathrm{~kJ} / \mathrm{kg}$ and the latent heats for soils $\left(L_{s}\right)$ were 59 and $10 \mathrm{~kJ} / \mathrm{kg}$ in Michigan and Alaska, respectively.

The model consisted of $25 \mathrm{~m}$ of waste and $1 \mathrm{~m}$ of cover soil. For each site, two levels of stable waste temperature and three levels of waste placement temperature were used. The lower boundary of the waste was set to a constant temperature that represented either zero or site-specific high heat generation in wastes. For zero heat generation, site-specific mean annual earth temperature $\left(T_{m}\right)$ was used. For high heat generation, summation of $T_{m}$ and time-averaged maximum temperature differential $\left(\Delta T_{\max }\right)$ due to waste heat production at a given site (Yesiller et al. 2005) was used. The $T_{m}$ values were $11.7,20.0,6.0$, and $11.5^{\circ} \mathrm{C}$ and the $\Delta T_{\max }$ values were $47.8,12.5,26.9$, and $44.0^{\circ} \mathrm{C}$ in Michigan, New Mexico, Alaska, and British Columbia, respectively. Initially, $20 \mathrm{~m}$ of waste was allowed to reach equilibrium under the seasonal temperature variations applied to the surface (function determined using the weighting factors). Then, an additional $5 \mathrm{~m}$ of waste was placed during one of three different seasons: summer, winter, and spring representing maximum, minimum, and average air temperatures at each site. Covers were placed immediately after the placement of the top $5 \mathrm{~m}$ of waste at the same temperature.

\section{Results}

\section{Cover Temperatures}

Examples of temperature variations in covers are provided in Fig. 4 for detailed arrays (Cells $\mathrm{A}$ and J-Michigan, Cell B 

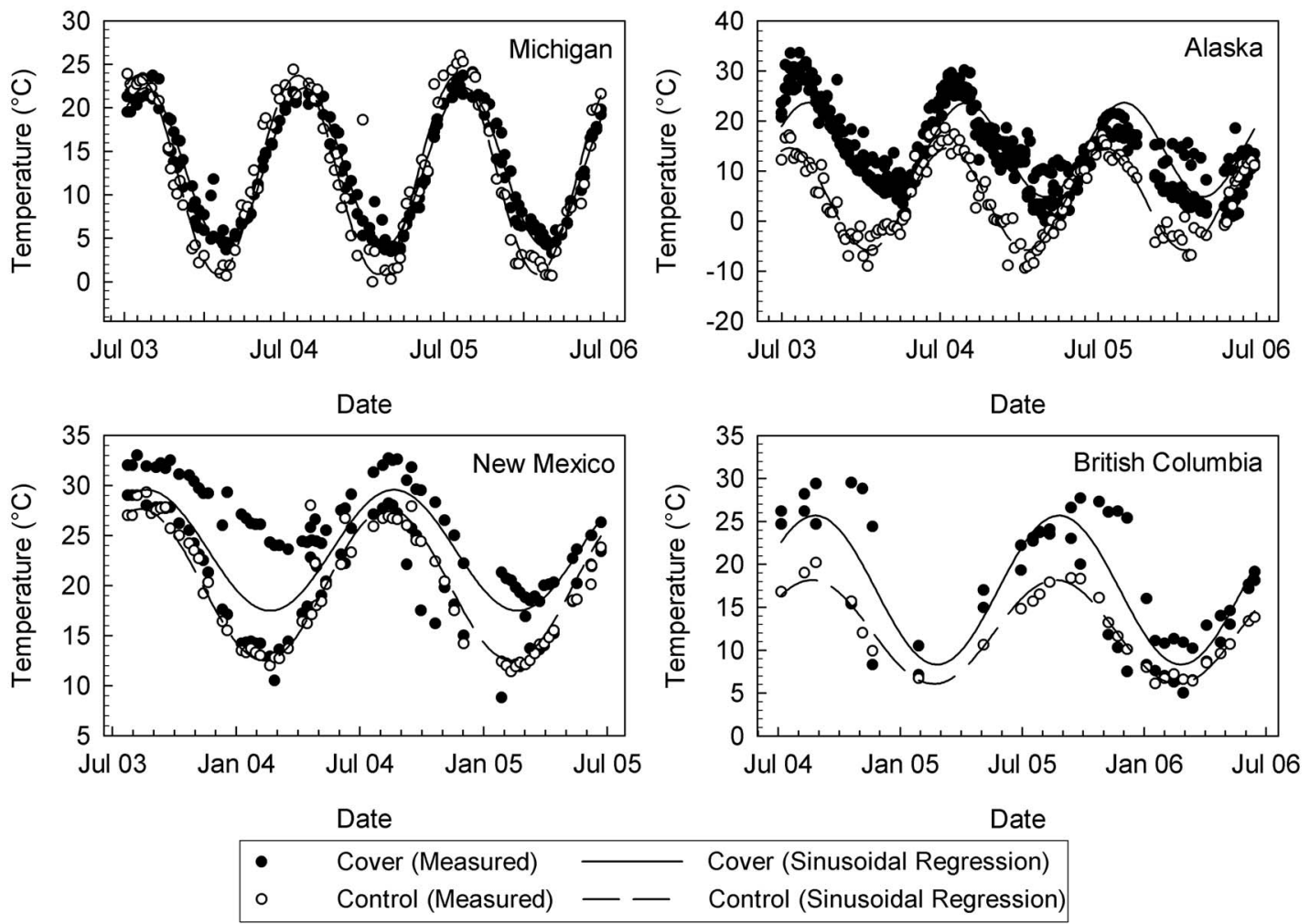

Fig. 5. Cover and control temperatures

detail-British Columbia). Air temperatures are presented using sinusoidal representations of measured data. Temperatures in the cover systems varied seasonally similarly to air temperatures and demonstrated amplitude decrement and phase lag with depth [Fig. 4(a)]. Maximum surface temperatures were $10-15^{\circ} \mathrm{C}$ higher for the east-facing Cell J cover than the north-facing Cell A cover due to the combined effects of greater solar exposure and younger underlying wastes. Minimum temperatures varied less between the cells at the surface. Temperature differences between the cells diminished with depth below the surface.

The surface temperatures were significantly different than the below surface temperatures in the cover profile in British Columbia. However, the temperatures generally varied less with depth than those in Michigan [Fig. 4(b)]. Temperatures along 72 and $24 \%$ of the tautochrones were within $2{ }^{\circ} \mathrm{C}$ in British Columbia and Michigan, respectively. This was attributed to variations in seasonal air temperature amplitude and moisture conditions between the sites. The amplitude in Michigan was almost twice the amplitude in British Columbia, resulting in a greater span of temperatures at the surface and higher thermal gradients with depth. In British Columbia, standing water was observed at the ground surface and throughout the depth of the cover soil due to high precipitation and passive leachate management. The high heat capacity of water prevented high-temperature changes through the cover profile at a given time.

Examples of cover and control temperature data for each site are provided in Fig. 5. Data from cells with young wastes are presented for British Columbia with comparable waste age to the other sites. All of the measured temperature data are summarized in Fig. 6. Maximum, minimum, and average cover temperatures at the sites are plotted for nominal depths of 0,1 , and $2 \mathrm{~m}$. For British Columbia, data are provided for old waste (greater than 13 years old) and young waste (less than 13 years old). Also, maximum, minimum, and average air temperatures (from sinusoidal regression) and mean annual earth temperatures at depth are presented in Fig. 6.

Cover temperatures differed from control temperatures at all sites (Figs. 5 and 6). The maximum, minimum, and average cover temperatures were generally higher than the corresponding control temperatures. The high differences in Alaska resulted from latent heat effects (significant phase change occurred in the control soils) and differences between thermal properties of the dense in situ native soil (control soil) and looser cover soils.

Variation in cover temperatures between multiple installations at a given site was low, except for New Mexico (Fig. 5). The temperatures at this site were higher at the edge than at the center by up to $6^{\circ} \mathrm{C}$ due to the high solar exposure from the south-facing external slope and high underlying waste temperatures (resulting from access to oxygen and excess moisture via the erosion gulleys on the slope) at the edge. Year-to-year variation in cover temperatures was generally low except for Alaska (Fig. 5). The average cover temperatures at 1 and $2 \mathrm{~m}$ depths decreased by approximately 6 and $5^{\circ} \mathrm{C}$, respectively, over the 3 -year measurement period. The extremely warm summer temperatures (significantly above seasonal averages) at the time of placement caused high initial temperatures. The combined cold climate and relatively low waste heat generation (Yesiller et al. 2005) resulted in a gradual decrease in temperatures.

In general, maximum temperatures decreased and the minimum temperatures increased with depth at the sites, resulting in decreases in the ranges of measured temperatures with depth. Average temperatures generally increased with depth (Fig. 6). The ranges of measured temperatures $\left(T_{\max }-T_{\min }\right)$ varied between 18.2 and $30.2{ }^{\circ} \mathrm{C}$ and between 12.9 and $21.4^{\circ} \mathrm{C}$ at 1 and $2 \mathrm{~m}$ depths, respectively. The average temperatures varied between 12.9 and $17.5^{\circ} \mathrm{C}$ and between 14.3 and $23.3^{\circ} \mathrm{C}$ at 


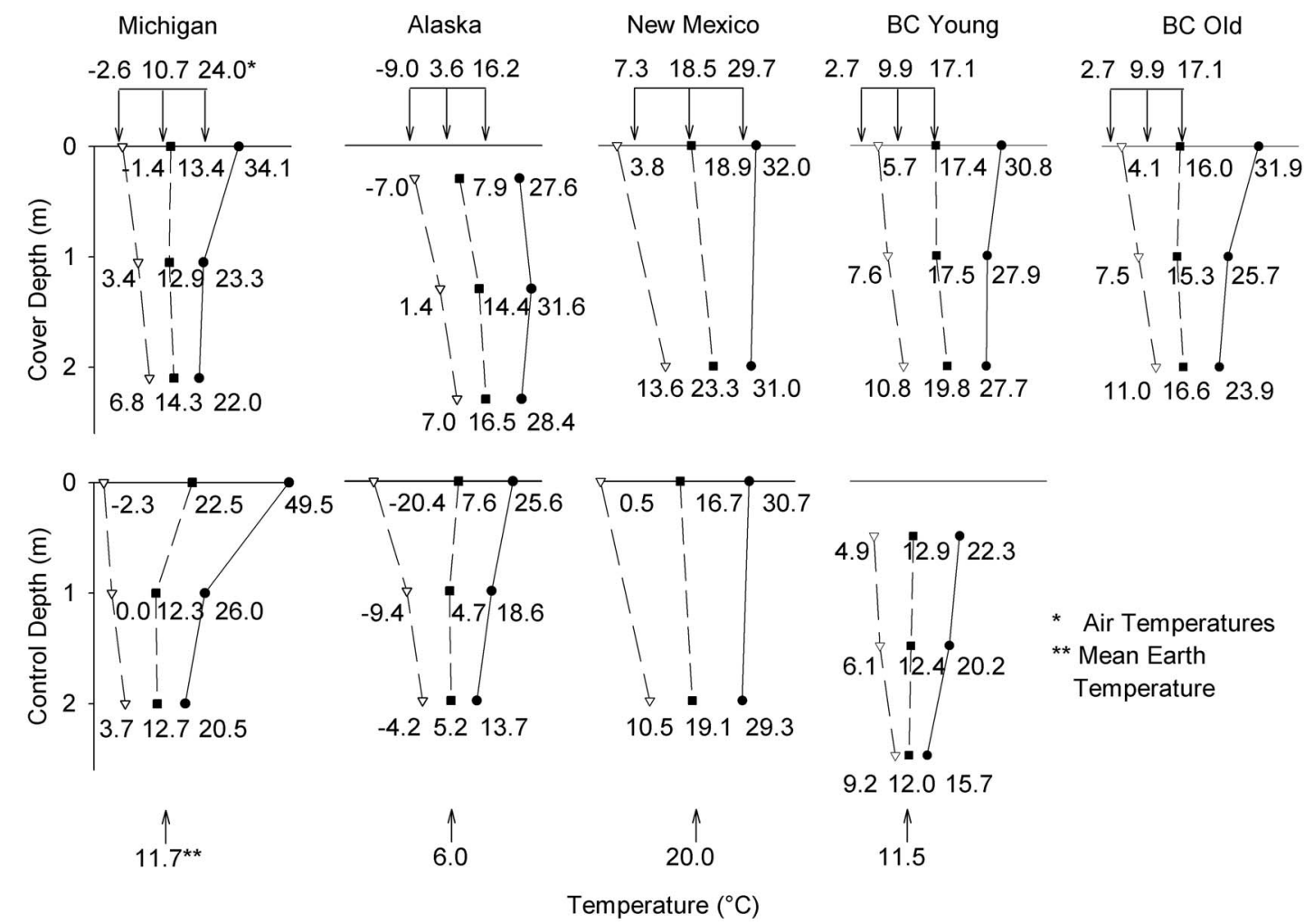

Fig. 6. Temperature envelopes for cover and control

1 and $2 \mathrm{~m}$ depths, respectively. Differences up to $4{ }^{\circ} \mathrm{C}$ were observed between covers in British Columbia above old and young wastes.

Overall, trends observed in cover temperatures with depth generally conformed to conventional earth heat transfer theory (Figs. 4-6). Seasonal variation was observed in the cover temperatures due to air temperature variations, while heat generation from the underlying wastes resulted in the warmer temperatures in the covers compared to the surrounding subgrade soils.

Frost depths were determined using the $0^{\circ} \mathrm{C}$ isotherm that was interpolated from the coldest tautochrones in Michigan and Alaska. The frost depths were 1.0 and $3.0 \mathrm{~m}$ in control arrays in Michigan and Alaska, respectively. In comparison, frost depths in covers were limited to $0.1-0.3 \mathrm{~m}$ in Michigan (freezing observed only once in each cell during the study) and 0.7-1.4 $\mathrm{m}$ in Alaska. The reduced frost penetration in the covers is attributed to relatively high underlying waste temperatures in comparison to unheated ground temperatures.

Temperatures in the barrier materials are presented in Table 3 for the detailed arrays in Michigan (geomembrane and compacted clay) and British Columbia (at a depth that would be expected to have a natural or geosynthetic barrier). The maximum and mini-

Table 3. Barrier Temperatures from Detailed Arrays

\begin{tabular}{lcrccc}
\hline Cell & Barrier & $\begin{array}{c}\text { Sensor } \\
(\mathrm{mm})\end{array}$ & $\begin{array}{c}T_{\max } \\
\left({ }^{\circ} \mathrm{C}\right)\end{array}$ & $\begin{array}{c}T_{\min } \\
\left({ }^{\circ} \mathrm{C}\right)\end{array}$ & $\begin{array}{c}\text { Range } \\
\left({ }^{\circ} \mathrm{C}\right)\end{array}$ \\
\hline Michigan A & Geomembrane & 900 & 23.1 & 2.7 & 20.4 \\
Michigan A & Compacted clay & 1,200 & 21.8 & 3.8 & 18.0 \\
Michigan J & Geomembrane & 1,050 & 24.1 & 3.5 & 20.6 \\
Michigan J & Compacted clay & 1,200 & 24.4 & 4.0 & 20.4 \\
British Columbia B detail & Soil/geosynthetic & 900 & 25.1 & 4.2 & 20.9 \\
\hline
\end{tabular}

mum temperatures for the barriers were $22-25^{\circ} \mathrm{C}$ and $3-4{ }^{\circ} \mathrm{C}$, respectively. While the maximum barrier temperatures were similar to typical temperatures used in determination of the properties and behavior of these materials, the minimum temperatures were significantly lower than the range of temperatures used, particularly in the laboratory. In addition, the barrier materials were subjected to significant seasonal temperature differentials on the order of $20^{\circ} \mathrm{C}$.

Data from horizontal arrays provided variations of temperatures at equivalent depths within a cover profile. The average temperature variations along the horizontal arrays were 4 and $3{ }^{\circ} \mathrm{C}$ in Michigan and Alaska, respectively, whereas the maximum variation was $10^{\circ} \mathrm{C}$ at the sites for a given measurement event. The horizontal variation of temperatures was determined to be normally distributed with a standard deviation of $1.8^{\circ} \mathrm{C}$ in Michigan and $1.1^{\circ} \mathrm{C}$ in Alaska.

\section{Thermal Gradients}

Measured instantaneous thermal gradients in the covers are summarized in Table 4 for $0-1$ and $1-2 \mathrm{~m}$ nominal depth intervals. The maximum and minimum cover gradients were 14 and $-18^{\circ} \mathrm{C} / \mathrm{m}$, respectively, with averages between -7 and $1^{\circ} \mathrm{C} / \mathrm{m}$. The average cover gradients were generally lower than the control gradients at comparable depth intervals. The gradients fluctuated seasonally between positive (downward heat flow) and negative (upward heat flow). In general, the majority of the cover gradients were negative, whereas the majority of the control gradients were positive. A greater fraction of the cover gradients was negative compared to the control gradients at each depth interval. Cover gradients in British Columbia (old) were slightly more positive than negative, indicating a reversal in the predominant direction of heat flow due to reduced waste heat generation. Examples of 
Table 4. Summary of Cover Gradients

\begin{tabular}{lrrrrc}
\hline Array & $\begin{array}{c}i_{\text {max }} \\
\left({ }^{\circ} \mathrm{C} / \mathrm{m}\right)\end{array}$ & $\begin{array}{c}i_{\text {min }} \\
\left({ }^{\circ} \mathrm{C} / \mathrm{m}\right)\end{array}$ & $\begin{array}{c}i_{\text {avg }} \\
\left({ }^{\circ} \mathrm{C} / \mathrm{m}\right)\end{array}$ & $\begin{array}{c}\left(i_{\text {abs }}\right)_{\text {avg }} \\
\left({ }^{\circ} \mathrm{C} / \mathrm{m}\right)\end{array}$ & $\begin{array}{c}\text { Percent } \\
\text { negative } \\
(\%)\end{array}$ \\
\hline Michigan 0 to 1 m & 14.3 & -9.2 & 0.5 & 5.2 & 55.0 \\
Michigan 1 to 2 m & 5.4 & -7.9 & -1.6 & 3.3 & 60.3 \\
Alaska 0.3 to 1.3 m & 6.6 & -17.5 & -6.5 & 7.4 & 84.1 \\
Alaska 1.3 to 2.3 m & 7.8 & -9.4 & -2.1 & 4.3 & 68.0 \\
New Mexico 0 to 2 m & 2.3 & -8.3 & -2.3 & 2.6 & 78.9 \\
British Columbia & 9.6 & -8.0 & 0.7 & 4.6 & 47.4 \\
(old) 0 to 1 m & & & & & \\
British Columbia & 4.4 & -4.1 & -0.9 & 2.0 & 64.4 \\
(old) 1 to 2 m & & & & & \\
British Columbia & 5.9 & -5.5 & -0.1 & 2.6 & 58.6 \\
(young) 0 to 1 m & & & & & \\
$\begin{array}{l}\text { British Columbia } \\
\text { (young) 1 to 2 m }\end{array}$ & 2.2 & -8.5 & -2.4 & 3.3 & 77.5 \\
\hline
\end{tabular}

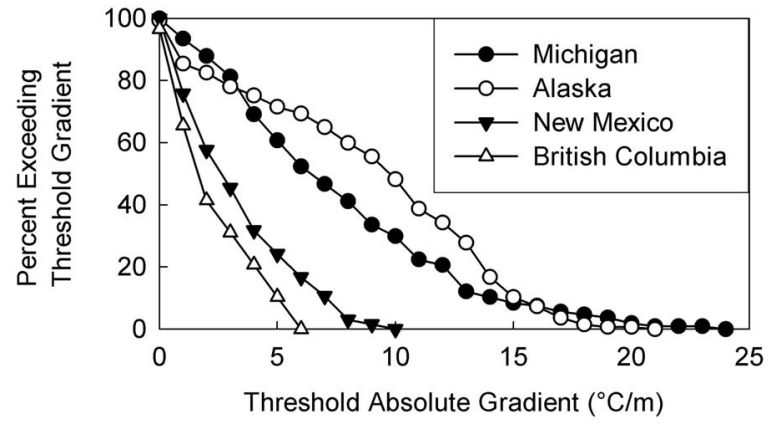

Fig. 7. Examples of frequency distribution of cover gradients

average absolute gradients that exceed specific threshold values are provided in Fig. 7 for each site. The cover gradients were high in Alaska and Michigan due to the comparatively high seasonal air temperature fluctuations. The average global thermal gradient $\left(i_{g}\right)$ was $-2^{\circ} \mathrm{C} / \mathrm{m}$ (i.e., average temperature increase with depth of $2{ }^{\circ} \mathrm{C} / \mathrm{m}$ ) at the sites. This nonzero value results from the presence of underlying wastes at temperatures above ambient conditions. Horizontal gradients were lower than $1{ }^{\circ} \mathrm{C} / \mathrm{m}$ at the sites.

Gradients in the barriers were analyzed in detail for the covers in Michigan and British Columbia. In Cell $\mathrm{A}$, gradients varied between -7 to $6^{\circ} \mathrm{C} / \mathrm{m}$ and -11 to $9^{\circ} \mathrm{C} / \mathrm{m}$ for $900-1,050$ and 1,050 to $1,200 \mathrm{~mm}$ depth intervals, respectively. The average gradients were -1 and $-2{ }^{\circ} \mathrm{C} / \mathrm{m}$ for $900-1,050$ and 1,050-1,200 mm depth intervals, respectively. In Cell J, gradients varied between
-11 and $5{ }^{\circ} \mathrm{C} / \mathrm{m}$ with an average of $-2^{\circ} \mathrm{C} / \mathrm{m}$ for the 1,050 $1,200 \mathrm{~mm}$ depth interval. In Cell $\mathrm{B}$ detail, gradients varied between -29 and $4{ }^{\circ} \mathrm{C} / \mathrm{m}$ with an average of $-2^{\circ} \mathrm{C} / \mathrm{m}$ for the 750-900 mm depth interval.

An example of variation of gradients with cover depth is presented in Fig. 8 for Cell $\mathrm{J}$ in Michigan. Analysis was conducted to determine timing and duration of relatively high gradients $\left(i>5^{\circ} \mathrm{C} / \mathrm{m}\right)$ in the detailed cover arrays for approximate locations of barrier components: $i_{900-1,050 \mathrm{~mm}}$ and $i_{1,050-1,200 \mathrm{~mm}}$ in Michigan and $i_{750-900 ~ m m}$ in British Columbia. The high gradients were observed in winter/spring months at both sites: October to March in Michigan and February to May in British Columbia. The gradients, $i_{900-1,050 \mathrm{~mm}}$ and $i_{1,050-1,200 \mathrm{~mm}}$ exceeded $5^{\circ} \mathrm{C} / \mathrm{m}$ for a maximum of 153 consecutive days in Michigan. The gradient, $i_{750-900 \mathrm{~mm}}$ exceeded $5^{\circ} \mathrm{C} / \mathrm{m}$ for a maximum of 91 consecutive days in British Columbia.

\section{Cover n-Factors}

In general, thawing $n$-factors were higher and the freezing $n$-factors were lower for the covers than control soils. Thawing $n$-factors for the covers were 1.02, 1.07, 1.38, and 1.29 for Michigan, New Mexico, Alaska, and British Columbia, respectively. The control thawing $n$-factors were $1.11,1.06,1.15$, and 1.23 for Michigan, New Mexico, Alaska, and British Columbia, respectively. The freezing $n$-factor for the Alaska cover was equal to 0.63 . Frost depths were reported for Michigan. However, the calculated surface freezing index was negligible compared to the air freezing index and therefore the freezing $n$-factor was essentially zero. The control freezing $n$-factors were 0.66 and 0.78 in Michigan and Alaska, respectively. The higher thawing $n$-factors and the lower freezing $n$-factors in covers were attributed to the presence of warm wastes beneath the covers.

\section{Design Charts}

The design charts for depths of limiting temperature range and frost penetration in covers are presented in Fig. 9 for $\alpha_{c}=8$ $\times 10^{-7} \mathrm{~m}^{2} / \mathrm{s}$ and $i_{g}=-2{ }^{\circ} \mathrm{C} / \mathrm{m}$. Temperature ranges that cover components are subjected to can be determined as a function of surface temperature amplitude for specific depths [Fig. 9(a)]. Depth of frost penetration in a cover can be determined as a function of average surface temperature and surface temperature amplitude [Fig. 9(b)].

\section{Numerical Analysis}

Results of the numerical analyses indicated that covers were subjected to variable ranges of temperatures in the period between

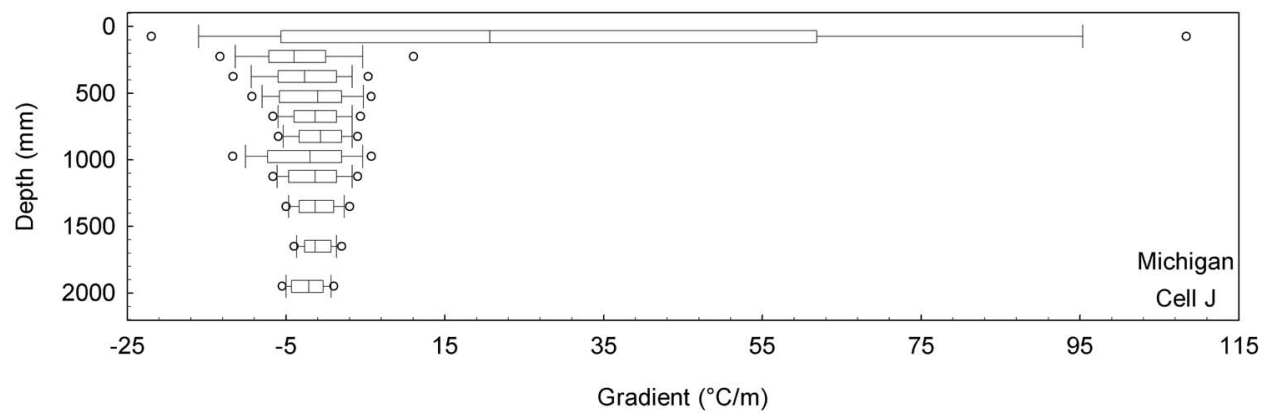

Fig. 8. Example of variation of cover gradients with depth 


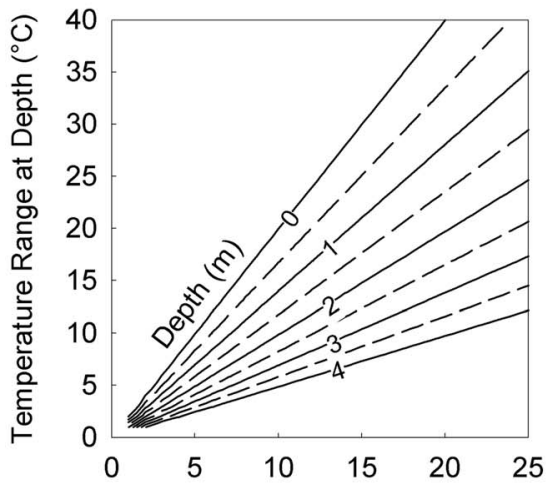

Surface Temperature Amplitude $\left({ }^{\circ} \mathrm{C}\right)$

(a)

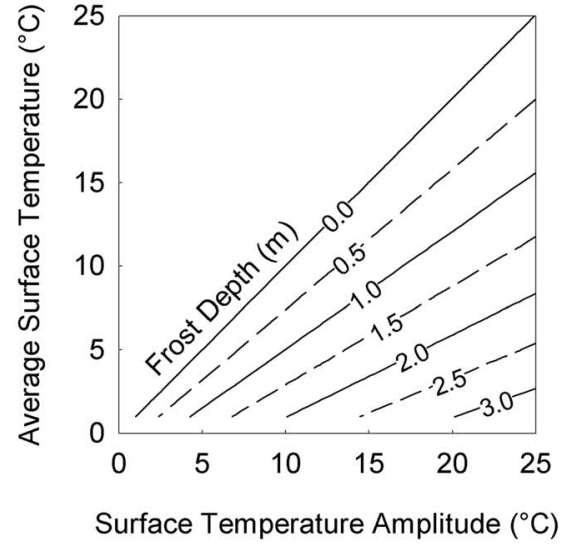

(b)

Fig. 9. Design charts: (a) temperature range; (b) frost depth

cover installation and the onset of long-term annual temperature cycle stasis that occurred approximately 3 years after placement. In the short term, cover temperatures were affected by the timing of near-surface waste placement (top $5 \mathrm{~m}$ of waste). Long-term cover temperatures varied up to $3{ }^{\circ} \mathrm{C}$ due to variable underlying waste temperatures representing zero and high heat generation at depth. The ability of the wastes to conduct and store heat (i.e., thermal inertia) affected the overlying cover temperature response. The maximum ranges of temperatures $(R)$ for service life of covers were determined to range from $14-26^{\circ} \mathrm{C}, 17-29^{\circ} \mathrm{C}$, and $14-26^{\circ} \mathrm{C}$ for summer, winter, and spring placement, respectively. The maximum differentials between cover temperature at time of placement and any future modeled temperature extreme ranged from $10-22^{\circ} \mathrm{C}, 19-29^{\circ} \mathrm{C}$, and $10-17^{\circ} \mathrm{C}$ for summer, winter, and spring placement, respectively. The equilibrium cover

Table 5. Temperature Guidelines for Covers

\begin{tabular}{lccrrr}
\hline & $\begin{array}{c}\text { Nominal } \\
\text { Septh } \\
\text { Site }\end{array}$ & $\begin{array}{c}T_{\max } \\
(\mathrm{m})\end{array}$ & $\begin{array}{r}T_{\min } \\
\left({ }^{\circ} \mathrm{C}\right)\end{array}$ & $\begin{array}{c}T_{\text {avg }} \\
\left({ }^{\circ} \mathrm{C}\right)\end{array}$ & $\begin{array}{c}\text { Range } \\
\left({ }^{\circ} \mathrm{C}\right)\end{array}$ \\
\hline Michigan $^{\mathrm{a}}$ & 0 & 23.8 & -0.2 & 11.8 & 24.0 \\
& 1 & 22.3 & 4.1 & 13.2 & 18.3 \\
New Mexico $^{\mathrm{b}}$ & 2 & 21.2 & 8.0 & 14.6 & 13.3 \\
& 0 & 31.8 & 7.8 & 19.8 & 24.0 \\
Alaska $^{\mathrm{c}}$ & 2 & 29.8 & 17.3 & 23.6 & 12.4 \\
& 0 & 21.2 & -7.4 & 6.9 & 28.6 \\
British Columbia (old) $^{\mathrm{d}}$ & 1 & 23.6 & 4.8 & 14.2 & 18.8 \\
& 2 & 22.2 & 10.7 & 16.5 & 11.6 \\
& 0 & 23.6 & 1.8 & 12.7 & 21.8 \\
British Columbia (young) $^{\mathrm{d}}$ & 1 & 22.3 & 7.6 & 15.0 & 14.7 \\
& 2 & 21.5 & 11.1 & 16.3 & 10.5 \\
& 0 & 26.5 & 0.7 & 13.6 & 25.8 \\
& 1 & 26.3 & 7.7 & 17.0 & 18.7 \\
& 2 & 26.5 & 12.3 & 19.4 & 14.3 \\
\hline
\end{tabular}

${ }^{a}$ Michigan: average daily air temperature $=9.8^{\circ} \mathrm{C}$, annual precipitation $=835 \mathrm{~mm}$.

${ }^{\mathrm{b}}$ New Mexico: average daily air temperature $=18.2^{\circ} \mathrm{C}$, annual precipitation $=240 \mathrm{~mm}$.

${ }^{\mathrm{c}}$ Alaska: average daily air temperature $=2.3^{\circ} \mathrm{C}$, annual precipitation $=408 \mathrm{~mm}$.

${ }^{\mathrm{d}}$ British Columbia: average daily air temperature $=9.9^{\circ} \mathrm{C}$, annual precipitation $=1,167 \mathrm{~mm}$. temperatures were identical in the long term for the variable initial seasonal placement conditions. An example of model predictions for variable seasonal placement of near-surface wastes in Michigan is presented in Fig. 10 for high heat generation.

\section{Guidelines for Thermal Conditions in Covers}

The measured data were used to develop guidelines for expected cover temperatures and frost depths at landfills in climatic regions similar to the study sites. These guidelines can be used in design, experimental testing, and numerical modeling of cover systems for prediction of long-term performance. While the functions determined using the weighting factors were used at the surface, sinusoidal regression functions of the measured data were used at depth. Maximum, minimum, and average temperatures and ranges of temperatures are provided in Table 5 for the four climatic regions included in the study for waste ages ranging from 4 to 13 years except for British Columbia (old), which represented waste ages from 13 to 40 years.

For analysis of covers in other climatic regions, $n$-factors developed in this study can be used to estimate surface temperatures from air temperature data. The recommended $n$-factors are 1.2 and 0.6 for thawing and freezing, respectively. Alternatively, control $n$-factors can be increased and decreased by 0.1 for thawing and freezing in covers, respectively. For modeling temperatures within covers using analytical approaches, a thermal diffusivity of $8 \times 10^{-7} \mathrm{~m}^{2} / \mathrm{s}$ and an increase in average temperature with depth of $2{ }^{\circ} \mathrm{C} / \mathrm{m}$ can be used. Based on temperature-depth relationships obtained in the study, frost depths in covers can be conservatively estimated to be approximately $50 \%$ of frost depths for soils at ambient conditions. High-temperature differentials in covers can be minimized by avoiding winter construction of covers.

\section{Summary and Conclusions}

This study was conducted to provide realistic thermal service conditions for cover systems. Spatial and temporal variations of temperatures in covers were determined at four MSW landfills located in different climatic regions in North America: Michigan, New Mexico, Alaska, and British Columbia. Field data were collected for periods up to 3 years.

Temperatures in the cover systems varied seasonally similarly to air temperatures and demonstrated amplitude decrement and 

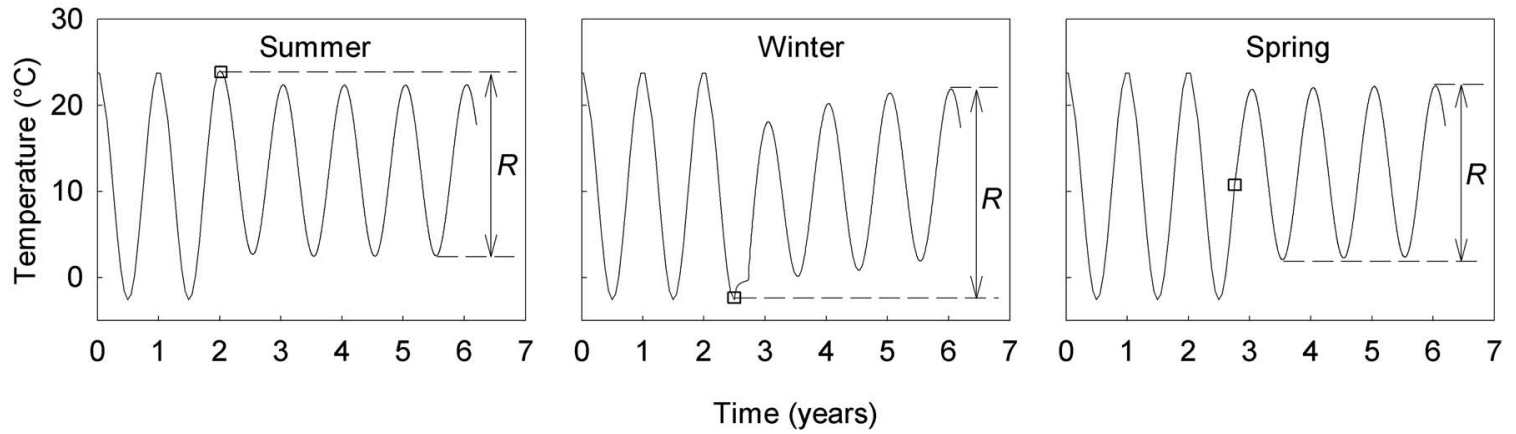

Fig. 10. Modeling results illustrating effects of timing of waste placement

phase lag with depth. Heat generation and elevated temperatures in the underlying wastes resulted in warmer temperatures and lower frost penetration in the covers compared to nearby subgrade soils. While seasonal air temperature fluctuations were predominant in controlling cover temperatures, the presence of underlying wastes at elevated temperatures also influenced cover temperatures and thermal properties. In general, maximum temperatures decreased and minimum temperatures increased with depth, resulting in decreases in the ranges of measured temperatures with depth. Average temperatures generally increased with depth at the sites. The ranges of measured temperatures $\left(T_{\max }-T_{\min }\right)$ varied between 18.2 and $30.2^{\circ} \mathrm{C}$ and between 12.9 and $21.4^{\circ} \mathrm{C}$ at 1 and $2 \mathrm{~m}$ depths, respectively. The average temperatures varied between 12.9 and $17.5^{\circ} \mathrm{C}$ and between 14.3 and $23.3^{\circ} \mathrm{C}$ at 1 and $2 \mathrm{~m}$ depths, respectively. For soil and geosynthetic barrier materials around $1 \mathrm{~m}$ depth, the maximum and minimum temperatures were $22-25^{\circ} \mathrm{C}$ and $3-4{ }^{\circ} \mathrm{C}$, respectively. While the maximum temperatures were representative of temperatures used in analysis of these materials, the minimum temperatures were significantly lower than the range of temperatures typically used in barrier design and analysis. The prevailing direction of heat flow in the covers was upward (negative gradients) and the maximum and minimum cover gradients were 14 and $-18^{\circ} \mathrm{C} / \mathrm{m}$, respectively, with average gradients in the range of -7 to $1^{\circ} \mathrm{C} / \mathrm{m}$. The gradients for barrier materials around $1 \mathrm{~m}$ depth varied between -11 and $9{ }^{\circ} \mathrm{C} / \mathrm{m}$ with an average of $-2{ }^{\circ} \mathrm{C} / \mathrm{m}$.

For analysis of covers in climatic regions similar to the study sites, guidelines provided herein can be used. For analysis of covers in other climatic regions, $n$-factors of 1.2 for thawing and 0.6 for freezing can be used to obtain cover surface temperatures from air temperatures. Alternatively, conventional $n$-factors for local ground surface conditions can be increased and decreased by 0.1 for thawing and freezing, respectively, for use in covers. For modeling temperatures within covers using analytical approaches, a thermal diffusivity of $8 \times 10^{-7} \mathrm{~m}^{2} / \mathrm{s}$ and an increase in average temperature with depth of $2^{\circ} \mathrm{C} / \mathrm{m}$ can be used. Frost depths in covers can be conservatively estimated to be approximately $50 \%$ of ambient soil frost depths.

\section{Acknowledgments}

This study has been supported by the National Science Foundation (GOALI Grant No. CMS-9813248 and SGER Grant No. CMS-0301032) and partner landfills (Sauk Trail Hills Development, Corralitos Regional Landfill, Anchorage Regional Landfill, and Vancouver Landfill).

\section{References}

Albrecht, B., and Benson, C. H. (2001). "Effect of desiccation on compacted natural clays." J. Geotech. Geoenviron. Eng., 127(1), $67-76$.

Aldrich, H. P., and Paynter, H. M. (1953). "Analytical studies of freezing and thawing of soils." Frost Investigations, Fiscal Year 1953, First Interim Report, Technical Rep. No. 42, U.S. Army Corps of Engineers, Artic Construction and Frost Effects Laboratory, New England Division, Boston.

Andersland, O. B., and Ladanyi, B. (2003). Frozen ground engineering, 2nd Ed., Wiley, New York.

Benson, C. H., Abichou, T. H., Olson, M. A., and Bosscher, P. J. (1995). "Winter effects on hydraulic conductivity of compacted clay." J. Geotech. Engrg., 121(1), 69-79.

Benson, C. H., and Othman, M. (1993). "Hydraulic conductivity of compacted clay frozen and thawed in place." J. Geotech. Engrg., 119(3), 276-294.

Borjesson, G., and Svensson, B. H. (1997). "Seasonal and diurnal methane emissions from a landfill and their regulation by methane oxidation." Waste Manage. Res., 15(1), 33-54.

Bouazza, A., Vangpaisal, T., and Jefferis, S. (2006). "Effects of wet-dry cycles and cation exchange on gas permeability of geosynthetic clay liners." J. Geotech. Geoenviron. Eng., 132(8), 1011-1018.

Carslaw, H. S., and Jaeger, J. C. (1959). Conduction of heat in solids, 2nd Ed., Oxford University Press Inc., New York.

Doll, P. (1997). "Desiccation below mineral liners with heat production." J. Geotech. Geoenviron. Eng., 123(11), 1001-1009.

Koerner, G. R., and Koerner, R. M. (2006). "Long-term temperature monitoring of geomembranes at dry and wet landfills." Geotext. Geomembr., 24, 72-77.

Koerner, R. M. (2005). Designing with geosynthetics, 5th Ed., PrenticeHall, Upper Saddle River, N.J.

Koerner, R. M., and Koerner, G. R. (2005). "In-situ separation of GCL panels beneath exposed geomembranes." GRI White Paper No. 5 , Geosynthetic Institute, Folsom, Pa.

Landsberg, H. E., Lippmann, H., Paffen, K. H., and Troll, C. (1966). World maps of climatology, 3rd Ed., E. Rodenwaldt and H. J. Jusatz, eds., Springer, Berlin.

Liu, W.-L. (2007). "Thermal analysis of landfills." Ph.D. thesis, Wayne State Univ., Detroit.

Meteorological Service of Canada (MSC). (2007). "Climate database." 〈http://www.msc-smc.ec.gc.ca/contents_e.html〉 (Sept. 23, 2007).

Mitchell, J. K., and Soga, K. (2005). Fundamentals of soil behavior, 3rd Ed., Wiley, Hoboken, N.J.

National Climatic Data Center (NCDC). (2006). "Climate database." 〈http://www.ncdc.noaa.gov./〉 (Sept. 15, 2006).

National Research Council (NRC). (2007). Assessment of the performance of engineered waste containment barriers, National Academies Press, Washington, D.C. 
Oak Ridge National Laboratory (ORNL). (1981). "Regional analysis of ground and above-ground climate." Rep. No. ORNL/Sub-81/40451/1, U.S. Dept. of Energy, Office of Buildings Energy R\&D, Oak Ridge, Tenn.

Oettle, N. K. (2008). "Thermal analysis of landfill barriers." MS thesis, California Polytechnic State Univ., San Luis Obispo, Calif.

Rowe, R. K. (2005). "Long-term performance of containment barrier systems." Geotechnique, 55(9), 631-667.

Soong, T.-Y., and Koerner, R. M. (1999). "Behavior of waves in high density polyethylene geomembranes: A laboratory study." Geotext. Geomembr., 17, 81-104.

Southen, J. M., and Rowe, R. K. (2005). "Laboratory investigation of geosynthetic clay liner desiccation in a composite liner subjected to thermal gradients." J. Geotech. Geoenviron. Eng., 131(7), 925935.

Yesiller, N., Hanson, J. L., and Liu, W.-L. (2005). "Heat generation in municipal solid waste landfills." J. Geotech. Geoenviron. Eng., 131(11), 1330-1344. 